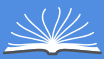

Global Journals Inc.

की

\title{
Ritual \& Practices to Attain Spirituality in the Light of Religious Scriptures of the World Religion
}

By Tayyaba Razzaq

University of the Punjab

Abstract- Humans are spiritual beings and preferred to be an element (one way or the other) of this potent mighty power that fascinated him. Men have been urged to look or visualize the Mighty Lord. Different kind of tools and means were designed in various religious communities to offer a few beautified methods to meet this fundamental intuition. To attain spirituality, many ancient religions had their own rituals and ceremonial systems that mostly consist of external rites and practices. The purpose of the study is to examine and determine the importance of rituals that are being practice in the world religions? What the methods religious scriptures has mentioned for their followers to adopt to attain spirituality? The study is to find out similarities and differences in rituals \& practices to attain spirituality as mentioned in their religious scriptures? Research methodology for this study adapted is descriptive. This research study has fined out that some ritual systems are concerned with inwards purification rather than outwards. The major purpose of all such practices; fasting, sacrifices, charity etc are all to free men from the entire evil deeds, make him pure as the will of the Lord and closer to it.

Keywords: rituals, spirituality, ceremonies, religious- scriptures.

GJHSS-A Classification: FOR Code: 440204

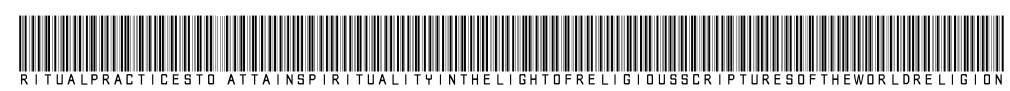

Strictly as per the compliance and regulations of:

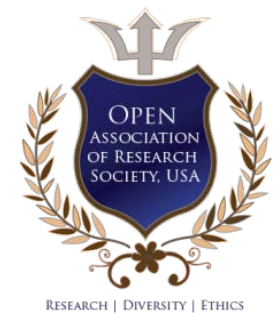

(c) 2019. Tayyaba Razzaq. This is a research/review paper, distributed under the terms of the Creative Commons AttributionNoncommercial 3.0 Unported License http://creativecommons.org/licenses/by-nc/3.0/), permitting all non-commercial use, distribution, and reproduction in any medium, provided the original work is properly cited. 


\title{
Ritual \& Practices to Attain Spirituality in the Light of Religious Scriptures of the World Religion
}

\author{
Tayyaba Razzaq
}

Abstract- Humans are spiritual beings and preferred to be an element (one way or the other) of this potent mighty power that fascinated him. Men have been urged to look or visualize the Mighty Lord. Different kind of tools and means were designed in various religious communities to offer a few beautified methods to meet this fundamental intuition. To attain spirituality, many ancient religions had their own rituals and ceremonial systems that mostly consist of external rites and practices. The purpose of the study is to examine and determine the importance of rituals that are being practice in the world religions? What the methods religious scriptures has mentioned for their followers to adopt to attain spirituality? The study is to find out similarities and differences in rituals \& practices to attain spirituality as mentioned in their religious scriptures? Research methodology for this study adapted is descriptive. This research study has fined out that some ritual systems are concerned with inwards purification rather than outwards. The major purpose of all such practices; fasting, sacrifices, charity etc are all to free men from the entire evil deeds, make him pure as the will of the Lord and closer to it.

Keywords: rituals, spirituality, ceremonies, religiousscriptures.

\section{INTRODUCTION}

$\mathrm{R}$ itual performances are different in the world religion. Some rituals are long, complicated events combining oratory, song, dance, costuming, staging and sometimes requiring travel from one location to another. All of this has to be coordinated individual rituals performers may have to enact their character through gesture, dance, and dialogue. In case of illusion and possession, one even has to alter his state of consciousness. To attain spirituality by following particular rituals \& practices were in all world religion by simple ablution, bath and make sacrifice and distinctive features etc.

"Our religious ceremonies are but the shadows of that great universal worship celebrated in the heavens by the legions of heavenly beings on all planes, and our prayers drill a channel across this mist separating our earthbound plane from the celestial ones through which a communication may be established with the powers that be."

(Pir Vilayat Inayat Khan)

Author: PhD Scholar, Institute of Islamic Studies, University of the Punjab, Lahore, Pakistan. Visiting Lecturer, Sheikh Zyed Islamic Center, University of the Punjab, Lahore, Pakistan.

e-mail: razzaqtayyaba@gamil.com a) Practices in Judaism

In Judaism spiritual purification has constitutional sense. The outward purity is the fount of inward impurity. Some major rituals are mentioned in Torah and particularly in the book of Leviticus 14:4-32.

There are some common practices of daily life in Jews. They are used to touch "Mezuzah" whenever they enter and go outside of their house. Mezuzah is a written text of their religious scripture fixed on the door panel of their houses.

It is obligatory for a Jew to wear 'Tephillim' and 'Tallith' generally and particularly at worship time. Teffillin is known as a religious sign' Jews used it in their prayers. It is a sort of leather in black color tie up it to the forehead and left arm till hand while Teffillin contained selected portions of Torah. (Deuteronomy 6:8)

Physical cleanliness is performed as commanded by the religion. Washing hands has been also done formally (Mark 7:3-4). Some sort of special purity before the 'Passover' is also compulsory for them. (John 11:55) 'Mikhvah' is the ritual bath in Jewish community. Observance of 'Sabbath' as a special day is obligatory in Judaism. They are not allowed to do any kind of work on the day. This day is only for the remembrance of the Lord and a test of believe. They are ordered to guard 'Sabbath'. (Leviticus 19:30) The ceramics has been also washed as a ritual observance.

In some cases ritual ceremonies for purification purpose becomes mandatory if someone come in contact with a dead body or grave as described in Torah.

b) Practices s in Christianity

Different Rituals in the church have been performed to achieve spirituality and physical preparation is the first of all' especially by the priest before going in front of the God' according to the book of Leviticus 22:1-33.

A layman stands when the priest (celebrant) enters with his ministers to go to the altar; then the congregation kneels and cross themselves whiles the choir, with or without musical accompaniment, begins the introit. After invoking the Trinity and saying Psalm 42, the confession of sins and absolution given. The canon of the Mass, the central part, begins with the offering of the elements, the commemoration of the Virgin, Apostles, martyrs, and the consecration. 
As the host (bread or wafer) and the wine are consecrated they are elevated, a bell rings thrice each, and the people kneel and adore twice. The host is broken over the chalice and a particle dropped in; the Agnus Dei (Lamb of God) is chanted, and the kiss of peace given at a solemn Mass. The celebrant then receives the host himself. If there is a Communion, which is not normal at High Mass, a cloth is spread in front of the Communion rail, the deacon or server repeats the confession, the priest brings in the consecrated host (one kind only, the wafer) and administers it to the people at the rail. The priest then cleanses and veils the vessels and pronounces the benediction. The service ends with the first part of the first chapter of the Gospel according to St. John. ${ }^{1}$

\section{c) Rituals in Islam}

In Islam, five times prayers are mandatory to all Muslims. It is a vital characteristic of a Muslim as the holy Quran says: "undoubtedly their prayer confines them from disgraceful and misdeeds / sins."(AlAnkaboot 29:45)

The pilgrimage is the peak of physical as well spiritual domain of spiritual purification mentioned in the religion. This is an obligatory act to perform "Hajj" for every Muslim once in the whole life. (Al- Imran 3:97). "When a person commits to perform Hajj, must avoid any kind of; vulgarity, corruption and quarrel."(AlBaqarah, 2:197)

It is suggested in Islam to give alms "zakat" to help poor's by the wealthier. It helps to attain spirituality as the love of money captured the men and spending the money in the obedience of Allah makes men closer to the mighty Lord. Quran has stressed at many places in it to pay charity and help needy.

'Mahfil-i-Sama' has been conducted as a practice of Muslims community' particularly in SubContinent. Sama; At the Urs festival held on 'dargah' of a Sufi or a saint, Sama mehfil conducted mostly. Qawaals usually sit towards the feet of the Sufi in the courtyard. Devotees sit on either side, leaving the center path free of obstruction. Clapping is strictly forbidden because these assemblies are not music concerts but a form of prayers. Sufis believe spiritual music assemblies provided nourishment to the soul. The eventual purpose is the state of "fana" annihilation, in God way. ${ }^{2}$

\section{d) Rituals in Hinduism}

Hindu religious rituals have different requirements like some gifts to present the gods, some eatables' like rice, milk, honey, water, and some other things like clothes, tulasi leaves, jewelry, scents, flowers, incense, lights, food etc.

\footnotetext{
${ }^{1}$ Worship in the World Religion, 216-217.

2 The Sufi courtyard, Dargahs of Delhi, 21.
}

Hindu Rituals practices are synonymous with good 'karma'. They perform some rituals to be purified spiritually. It includes Puja, Prarthanas, Dhupa, Dipam and Achamanam. ${ }^{3}$

In Hinduism self-transformative practices such as austerity (tapah), celibacy (Brahmacharya), regulated breathing (pranayama), concentration (Dharana), contemplation (Dhyana), contemplation of God (Nidhi Dhyasa) and silence or restraint of speech (Mauna) are important spiritual practices. Prayer is obligatory and week days are fixed for particular god or godess; Shiva, Hanuman, Krishna, Dakshinamurthy, Maha Lakshmi, Shani Gayatri and Surya Gayatri.(Chandogya Upanishad, VIII. 5.1 - VIII. 5.4)

Some other physical and spiritual practices are mental worship (manasa puja), recitation of God's names (japa), devotional singing (kirtana and bhajana), devotional services (charya) such as sweeping the temple flour, preparing the ritual material and serving the guru.

The six yogic practices (kriyas) namely Netī (nostril cleaning), Dhautī (cleaning of the digestive and respiratory tracts), Naulī (cleaning of the abdominal in circular motion), Basti (cleaning of the lower abdomen), Kapālabhātī (cleansing of the brain), Trāțaka (a meditative technique to awaken the third eye) are also purification practices only.

In Hinduism, bath is a ritual obligation named the 'snana, for purification 'sodhana' performed in river water. Fire bath is also taken by jumping, walking and standing or sitting position. Air bath and dust bath have been also performed as religious ritual for purification purpose.

In ancient times it believed in that cow was created on the same day as Brahma' and killing cow is as sinful as of brahminicide and comes out of cow is sacred. Not only dairy products uses but the urine and dung also. Pancha -gavya, (five cows) are five products of cow; ghee/ butter, curds, cow dung and cow urine. The drink of go-mutra (cow urine) is still practiced by the devotees and women before and after delivery. Some sacred Hindus directly drink from urinating cow. Cleaning, snana or bath in cowurine is also a form of purification. Panchagavya or panchakavyam is mixture of five products of cow, used in traditional Indian rituals.

A bright yellow pigment known as gorochana, prepared from gallstone of a cow, is used for making sectarian marks on body; mixed with cow dung it is taken as a tonic and applied to the genitals. In villages the floors and the hearth of mud huts are daubed with freshly mixed cow dung and earth to purify and clean them. There is go-prachara (cow pasture) or sacred spots in many places of pilgrimage, where hoof prints, representing the hoof prints of Krishna's cows are

\footnotetext{
${ }^{3}$ Jayaram V, 'Suddhi, Purity and Cleanliness in Hinduism', retrieved from http://www.hinduwebsite.com/hinduism/h_purification.asp.
} 
worshipped. In ante mortem ritual the hands of the dying person tie up with cow tail and believed in that cow will take him to paradise. The astrological predicts something bad about a child, so he needed to pass under the tummy of a cow so he could rebirth again.

'Jata -Karrma' is an event when a Brahmani (women) going to deliver a child, her husband must be closer to note down time, day, star etc. The filthy condition has been continuous for ten days. Not only the woman considered impure but the rest of all member of this home also considered polluted for ten days. ${ }^{4}$

e) Practices in Buddhism

Buddha did not believe in performing rituals only, but in righteous actions. 'Eightfold path' is the foundation of ethical living of a Buddhist. Passing through the path one can lead to good 'karma' and resolve of past suffering.

In Buddhism, there is the system of rituals for spiritual purification (Suddhi). It is found in Pali scripture. Three rites and practices to gain suddhi are "asceticism, baptism and fire rituals". Buddhist takes very less diet in daily routine that mostly consist of vegetable only.

According to Buddha, in whatever way or manner' a man uses his body, his verbal expressions and his brain that's according to his wish and will. This is his entire silhouette. If he performs good deeds, will his get reward inverse in the next world. (DutiyaAputtakasuttam 51-52) So his performance not only counts his spirituality in this world but also the life hereafter depends upon his worldly deeds.

There are some rituals that only single can attend and perform like the Sennichi Kaihogyo. This is a festival conducted on mount Hiei (outside koyoto). ${ }^{5}$ Buddhists are advised takes very less diet in daily routine that mostly consist of vegetable only.

"Buddha has totally opposed to pilgrimage, sacred baths, adulatory and such other external practices which are mere mechanical in nature having no sanction of the inner heart."

\section{f) Rituals in Sikhism}

"Whatever pleases, are the only good deeds..." says Guru Nanak' in Guru Granth Sahib. To conduct a ceremony "presence of "Guru" is essential. The Guru is considered as sacred as the Holy Shrine by their spiritual leader and mentioned in Guru Granth Sahib. The Five Ks are the foundational custom of Sikhs. The five gadgets are: Keis (uncut hair), Kangha (comb),

\footnotetext{
${ }^{4}$ Dubois, J. A. (Jean Antoine), 1765-1848; Beauchamp, Henry K. (Henry King) (1906). Hindu manners, customs and ceremonies, Clarendon Press, oxford, 155

${ }^{5}$ Religions of the World, Buddhism, 138.

6 Kedar Nath Tiwari, (1987). Comparative Religion, India: Motilal Banarsidass, 177.
}

Kaṛa (metal bangle), Kirpān (quick sword) and kacchā (undergarment). ${ }^{7}$

Some rituals \& practices are also very essential; a Sikh must engage himself in remembrance of God (Naam Japna) Simran) on daily basis. One must be committed to Selfless service (Sewa) to community and shares his wealth with the needy and poor's (Wand ka Chakna). (Guru Granth Sahib)

In Guru Granth Sahib' Guru Nanak has taught that rituals, spiritual ceremonies or empty worship is of little use and Sikhs are discouraged from fasting or happening pilgrimages. However, at some stage in the duration of the later professionals, some ceremonies and rites did arise.

Gurdwaras is considered as a sacred place to worship so some rituals connected with it. Normally copy of Guru Granth is kept their. In the morning, Granth ceremonially carried to the temple from the treasury where it kept overnight and in the evening it is escorted back in the same manner.

\section{g) Rituals in Jainism}

Jainism is the religion believed in no god. According to them, God is not a supreme reality. Only good works or deeds, which collect like a deposit on the soul, make it light and rise upwards towards the reward. Bad deeds form a heavy deposit on soul and tied it to the material world in the endless cycle of existence. 'Ahmisa' is to do respect of all creature in the universe.

With regard to ritual purity and purification the Jain themselves says that they have borrowed their rituals from Hindus (Brahmins). A jain is always most anxious to maintain ceremonial purity, for only when a state of ritual holiness can he go to temple or monastery, or perform any of his religious duties, such as meditation, adoration, or reading the sacred book; but ceremonial pollution is very difficult to avoid, accruing, as it does, I so many minor ways. ${ }^{8}$

Jain monks are used to walk about in white cloth on their mouth to atop inhaling insects. They make vows not to kill, not to speak untruth, not to steal, to practice continence and to renounce pleasure in all outside things. They do not engage in butchering, fishing and any such profession that need to kill any living creature. They keep limited possessions. They do not cheat and lie with each other. Meditate regularly or on daily basis. Austerities (tapas) practices are for all Jains to abstain from intoxicants, meat, intoxicated drinks, gambling, hunting and adultery.

Svetambaras (white-clad) and Digambaras (sky-clad) are two main sects with some different rituals. Digambaras sect believed that as Mahavira went about naked so Nirvana cannot gain with clothing as Svetambaras have practiced.

\footnotetext{
${ }^{7}$ David Symonds, (1992). Believers All: A Book of Six World Religions UK: Nelson Thrones, 120-121.

${ }^{8}$ M. Sinclair Stevenson, (1915). Heart of Jainism, London: Oxford University Press, 258
} 
One important ritual for worshipper is to wash Tirthankara images. After removal of jewels, old flowers, it is washed with water, milk and five nectars and marked with liquid saffron in fourteen places of the body. Offering of rice (aksata puja) is made on a table in the shape of a crescent, in three heaps (three Jewels of religion) and swastika. Bhavapuja is the most important spiritual worship. He prostrates thrice in front of figure and remembers the honor, integrity of the Tirthankara by singing. On their return they utter the word Avassahi, with bowed hands towards the image.

\section{il. Some Common Practices \& Ritual in World Religions}

\section{a) Fasting}

Fasting is a common ritual to be observed by most of the religions of the world. It has been an almost universal practice of human race from early times. ${ }^{9}$

In both Old-Testament (Exodus 34:28 ; Leviticus 16:29-30) and New-Testament emphasis has been laid upon fasting and mentioned more than fifty times repeatedly to be spiritually purified' observe fast. Quran also says the same opinion as said; "Oh the people who believes, as (the people) before you so that you may become pious". (Al-Baqara, 2: 183)

In Judaism fasting is important as described the Ten Commandments that prophet Moses kept fasting for forty days and nights and he has written this command in the notepad of the commandments. (Exodus 34:28) To follow their prophet Jews normally kept fasting for fort days but the fast of the fortieth day is compulsory for them as the torah had laid much emphasis upon the fast on that day. The tenth day of the seventh month is considered the sacred day, so they keep on fasting at this day. This is the day of compensation to purify you. (Leviticus 16:29-30)

It was commanded to Jews to gather and observe fast for three days and nights. (Esther 4:16) Fasting was described as the practice to purify by the confession of sins and its compensation. (Nehemiah 9:1)

In the Judaic traditional law' only one day fasting was compulsory. The day called Yom Kipper. That was considered the 'Day of Atonement'. Judah's were ordered to observe fast fourth, fifth, seventh and tenth month of the year. (Zechariah 8:19) The prophet Moses fasted forty days on mount "Sanai, (Exodus 24:18; Psalm 69:10; Psalm 109:24) without drink water and anything eat. (Deuteronomy 9:9, 18) Jews were allowed to keep fast on some other days. Some evidences ${ }^{10}$ have been found that days were Monday

\footnotetext{
${ }^{9}$ Encyclopedia Americana; 12/52

${ }^{10}$ Encyclopedia of Religion, 5/287-288. Blacks Bible Dictionary, 198 ; Encyclopedia Britannica, 9/107
}

and Thursday. ${ }^{11}$ To purify one fasting, prayers and charity are tools to attain a pure life. ${ }^{12}$

In Christianity, 'fasting' is for the God to be spiritually purified and closer to the mighty one. (1 Corinthians 7:5) Fasting has been described as the quality of Mariam (blessings upon her) 'mother of Jesus' that she kept fasting and never left temple. (Luke 2:37) Christian disciplines were trained and persuaded by fasting for short and long term of. (Matthew 9:14; Matthew, 4:2; Mark 2:18; Luke 5:33; Acts 14:23) Purpose of fasting is patience and purity. As the person keep fast will be rewarded fully. (Matthew 6:16) Fasting is mentioned as a quality of piousness that "They prayed with fasting in every church." (Acts 14:23)

For Muslims, the fasting in the holy month of Ramadan inculcate feature of spirituality. As mentioned in the holy Quran; "O believers! Fasting is prescribed to you because it turned into prescribed to those before you, that you can (examine) self restraint."(Al-Baqarah 2:183)

'Ramadan' is the ninth month of the lunar year and the month in which the revelations of God are said to have come. During Ramadan all adult male and female Muslims must fast during the day-time, from the first light of dawn till the darkness at night. Children, the sick, pregnant women, and travelers are excused fasting, though the latter are expected to make it up some other time. (Al-Baqarah, 2:184- 185) Muslims keep the fast rigorously and abstain from all kind of food (cook or un-cook) and drink.

In Hindu Vedas and Shastras, fasting has been termed as "Vrat". Vart is observed for the Fire God. (Maadhyandin Yajurveda 1.5) Poornima (full moon) and Amavasya (no moon) are particular fasting days. Days are fixed for fasting in Hinduism for particular god or goddess like Shiva, Santoshi, hanuman and ganesha etc.

'Ikadishe' is the ninth month of Hindu calendar. It is a fast consisted on twenty four hours. During Ikadishe fast milk, fruits and vegetables are allowed to eat. One type of fast called "carwaachot" is obligatory to married women only. Some unmarried women also keep it for the long life of his expected husband.

Swami Chidananda enlists the benefits of fast "Fasting controls passion and emotions. It is the state of repentance of sins. Keeping fast can purify entire body system. A person becomes purer by repeated fasting." 13

In Buddhism, fifth and sixth months of the year are fixed for devotees of Buddha to observe fast. The four of the full moons are special fast days in 'Jainism' while in Sikhism; Guru Nanak Sahib denounced all

\footnotetext{
${ }^{11}$ Encyclopedia of Religion, 5/287-288. Blacks Bible Dictionary, 198 ; Encyclopedia Britannica, 9/107

12 Israel Abraham, Judaism, 45

${ }^{13}$ Swami Chidananda, (1993). Twenty Important Spiritual publication, A

Divine Life Society publications, 35
} 
beliefs of Hinduism and some of Islam. He denied fasting in any form. So there is no custom of fasting in Sikhs.

\section{b) Charity}

In Talmudic law to give "charity" amongst poor is also a religious ritual in Judaism. Land and vineyard are not be completely harvest and something left in the corners or ends of the field for needy and poor's. ${ }^{14}$ (Leviticus 19:9-10)All the production of field belongs to the Lord. If someone wants to recover possession must add fifth in it. Every tenth animal belongs to the lord, if you change it so both will be considered holy. (Leviticus 27:30-33) These corners and ends of field have been termed in "peach" and fallen of ripe crop as "gleaning" in Talmud. Alms and charity secures and increases your wealth as salt preserves the meat.

Islam suggests giving charity "zakat" to help poor's by the wealthier. Doing this the rich increase their wealth and seek blessing. ${ }^{15}$ It helps in purifying the soul by getting rid of the love for this world. Quran has laid more emphasis upon giving charity. (Al- Baqarah 2: 277 , Al-Zariat, 51: 19) This is why Allah says to the Prophet Muhammad (Peace Be upon Him): "Take charity from possessions to cleanse and purify them thereby." (AlTawbah 9:103)

In Sikhism, great stress is laid upon respect for humanity. "Adhi-Granth" has mentioned that a Sikh must offer his service for humanity, sharing of earning with the poor and needy. The free-food services for all, without distinction of religion and cast' are the most famous act of Sikhism.

c) Sacrifices

Sacrifice is to make offerings to God as an acknowledgement and thanks giving in Judaism and Christianity as well. Sacrifice $s$ are compensation for committed sins. According to Christianity the traditional sacrifice turned into a spiritual sacrifice. The bread and wine transformed into the body and blood of Jesus. (Hebrew 9:11; I Corinthians 15: 3-4 Romans 6:23) The Sacrifice of Communion is taken as symbolically in Catholics and is still in practice.

In Islam after performed 'Hajj' it is obligatory to offer sacrifice as Allah has demanded and said; "pray to your Lord and offer sacrifice". (Kausar, 108:2)

Fire (Agni) worship is also a part of Hind- rituals. Rig-Veda has given detail status of agony (fire).There are different types of fires; some are reserved for public sacrifices and some in domestic hearth. The construction of the sacred fire alter, the collecting of firewood, establishing fire with aid of rubbing sticks

\footnotetext{
${ }^{14}$ Takahashi, Y. (2007). A Study on Max Weber's "Ancient Judaism": Theoretical Framework and Methodology. Max Weber Studies, 7(2), 213229. Retrieved from http://www.jstor.org/stable/24579884: 47

${ }^{15}$ Muhammad Aslam, Muslim Conduct of state, 250
}

attended by rituals. The ritual of kindling the sacred fire is called "agnyadhey" that belongs to simple "srauta" sacrifices. ${ }^{16}$

In Buddhism, different kind of object presented as sacrifice. ${ }^{17}$ As Jains do not believe in any god, they do not offer any kind of sacrifice and 'Ahimsa' is their basic believe.

\section{d) Bath /Baptism}

Baptism is clearing or washing by application of water. It was only a religious rite in Jews that after presentation of sacrifices, a priest must clean himself with water, (Numbers 19:7, Hebrew 9:10) although the converts were never baptized until after the captivity. At the time of John the Baptist, proselytes from the gentile faiths were baptized as a symbol of renunciation of pagan errors and of their becoming pure for the services of Jehovah now they were cleansed from sin. John took the ceremony and adapted it to the new dispensation, which he was proclaiming a purifying for the reign of Messiah. Though Jesus never baptized, his discipline did it. (Matthew 3:6; Mark 1:4; John 1:19; Acts 19:4)

Mikhvah is a ritual bath in Judaism. After an intentional bath' called mikhvah' there are seven steps to dunk in water to be highly purified.

Baptism in Christianity is a ritual for slave or frees to be spiritually purified. (1 Peter 3:21) The purpose of Baptism is to wipe away sins, (Acts 22:16) repentance and confession on sins, it is believed in that God forgives sin and gives grace in sacrament of baptism. God makes free from the problem occupied man. He has faith in man's basic goodness and free will. Baptism is understood as a pledge or an acceptance of an infant by the group. Human reason and ethical responsibility is the key to salvation. ${ }^{18}$

The follower who does not practice baptism had been considered as ignorant child. (Luke 7:32) The sacraments of baptism (1 Peter. 3:21) and the Lord's Supper are explicitly provided for. Confession is linked with baptism and a prayer of thanksgiving with the breaking of bread. (1 Corinthians 11:24)

Ablution and bath in Muslims is obligatory but there is no ritual of baptism in Islam. (Al-Ma'idah 5: 6) In case of missing water ablution can be performed without water with pure dust mentioned in Quran. (AlNisa, 5:6)

In Hinduism, bath is a ritual obligation named the 'snana, for purification 'sodhana' performed in river water. ${ }^{19}$ Fire bath is also taken by jumping, walking and standing or sitting position. Air bath and dust bath have

\footnotetext{
${ }^{16}$ Benjamin Walker, (1968). Hindu World, An Encyclopedia Survey of Hinduism Vol: 1 London: George Allen s Un win Ltd, 359

${ }^{17}$ Religions of the World, Buddhism, 86

${ }^{18}$ An Introduction to Christianity, 19

${ }^{19}$ Benjamin Walker, (1968). Hindu World, An Encyclopedia Survey of Hinduism, Vol: 1, London: George Allen s Un win Ltd, 126
}

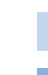


been also performed as religious ritual for purification purpose. ${ }^{20}$

Bath as a ritual in Hinduism is called 'ashnana, for 'sodhana' (to-purify). It is an obligation. Both personal cleanliness and spiritual sanctity are achieved by the same process, the difference lying in the intent. Snana is best performed in flowering water, preferably a river or spring. The sacred water of the Ganges also grants liberation. What does Ganga symbolize? Ganga was released from the head of Lord Siva and, therefore, represents the flow of knowledge. The Lord is the very first teacher from whom the knowledge has come down to us.

The most effective form of 'snana' is the archly, ritual bath in river, when the worshippers make oblation to the sun. Tanks, pounds and pools are also suitable for ceremonial baths particularly if they are scared. All such places are regarded as 'cross point' connecting the bathe with heaven and earth. The ritual bath involves the right of majjana, 'sinking' when the bather completely immerses his body in the water. A common ritual ablution is the 'avabhritha', a ceremonial bath taken before or even during a sacrifice. In the greater Vedic sacrifices the chief wife washed the back of the sacrifice and he washed his in return, after which they worship the sun.

Ritual baths are bathing in sacred water (rivers), with smoke (dhupa) and light (dipam). These rituals of 'achamanam' and 'abhisheka' (sprinkling of water) have been performed to remove the bad effects of evil-eye. The 'ganga-ashnan' is considered the only best way of purification.

Fire bath is also considered a type of ritual bath in Hinduism. This bath can be taken by jumping over a fire, or standing or sitting before one or more fires. In the ash-bath, often taken immediately after the fire- bath, the ashes of sacred plants are spared all over the body.

In the Air-Bath the naked body is vigorously rubbed while the god "Vayu" is invoked; it is necessary to perfume "pranayama" breathing exercises, and break wind while taking an air bath.

In the Dust Bath the dust raised by the hoofs of a cow is symbolically sprinkled on body and some dust applied on forehead. Washing in cow urine is a form of purification, snana or bath has been also performed.

'Puniaha-Vachana' (evocation of virtue) is to purify the house with sprinkling water. The ritualistic bhāradvāja clan invites the Buddha to go bathing in Bāhukā River. The Buddha asks what of the river Brahmin, what can I do? The reply is many consider it as a mean of deliverance and merit; many people let it bear away their evil deeds (karma). ${ }^{21}$

\footnotetext{
${ }^{20}$ Hindu World, An Encyclopedia Survey of Hinduism, 1/127-128

${ }^{21}$ Encyclopedia of Religion and Ethics, vol:10, 469
}

In Sikhism, baptism is an initiation ceremony, called "Amrita". A person baptize in the presence of five baptized Sikhs. The ceremony takes place in front of Guru Granth. Guru Gobind Singh (1675-1708) has given the name of Khalsa (pure) to only baptized Sikhs. Baptized ceremony is called 'ammrit sancar.' The first ceremony 'ammrit sancar' was conducted in Vaisakhi (1699) at Anandpur Sahib in India, here 'Guru Gobind Singh' and 'Panj Piare' baptized each other.

Baptized Sikhs are certain to wear the "Five Ks" in Punjabi referred to as pañj kakkē or pañj kakār. These are articles of religion at all times. The 10th guru, Gobind Singh, ordered these Five Ks (Kēs,karāā, kañghā, kirpān, kacchā ) to keep as practical and symbolic purposes. ${ }^{22}$

After this "Amrita" is prepared in iron vessel and the leader stirs it with a two-edged sword. They take oath to be obedient and faithful and promise to pray and pay tithes etc. Sikh Baptism (Amrit/ Khande Ki Pohul) have been celebrated by using drinking sacred water and singing hymns. A baptized Sikh can't haircut, infidelity, flesh-eating, smoking, drinking, and drugs.

\section{ili. Conclusion}

In contemporary period, every religion has its own identity. It has its own believes and practices. Some practices are commanded by their religious doctrines and some by their spiritual leaders or saints, generally called "rituals". These rituals acts are distinguish. The rituals are the overarching and subsume of devotion \& spiritualism. The purpose of such religious rituals and practices is to achieve spirituality. The purpose of all such rituals and practices like baptism, fasting, sacrifices, charity and even in routine life is to make control over the senses and obey the commandments of the religion. So the religion is the whole complex of distinctive spiritual, intellectual and emotional features that characterize a good or an ideal world.

\section{References Références Referencias}

1. Dubois, J. A. (Jean Antoine); Beauchamp, Henry K. (Henry King) 1906, Hindu Manners, Customs and Ceremonies, Oxford: Clarendon Press, 155.

2. David Symonds, 1992, Believers All: A Book of Six World Religions, UK: Nelson Thrones, 120-121

3. M. Sinclair Stevenson, 1915, Heart of Jainism, London: Oxford University Press, 258.

4. The Sufi courtyard, "Dargahs of Delhi", 21

5. Takahashi, Y. 2007. A Study on Max Weber's "Ancient Judaism": Theoretical Framework and Methodology. Max Weber Studies, 7(2), 213-229. Retrieved from http://www.jstor.org/stable/24579884: 47

6. Religions of the World, "Buddhism", 138.

\footnotetext{
${ }^{22}$ David Symonds, (1992). Believers All: A Book of Six World Religions, UK: Nelson Thrones, 120-121
} 
7. Kedar Nath Tiwari, 1987, Comparative Religion, India: Motilal Banarsi-dass, 177.

8. Muhammad Aslam, Muslim Conduct of state, 250

9. Swami Chidananda, (1993) Twenty Important Spiritual publication, A Divine Life Society publications, 35

10. Jayaram V, 'Suddhi, Purity and Cleanliness in Hinduism', retrieved from http://www. hinduwebsite. com/hinduism/h_purification.asp

11. Benjamin Walker, 1968, Hindu World, 'An Encyclopedia Survey of Hinduism' Vol: 1 London: George Allen \& Un win Ltd, 359, 126

12. Worship in the World Religion, 216-217

13. James. Hastings S. (1958) Encyclopedia of Religion and Ethics. New York: Boston Public Library. 10/469

14. Vivekananda. Swami, (1964) Complete Works,( Vol. III, p: 288) India: Advaita Ashram.

15. Muhammad Aslam, Muslim Conduct of state, 250 Encyclopedia of Religion, 5/287-288.

16. Blacks Bible Dictionary, 198 Encyclopedia Britannica, 9/107 Israel Abraham, Judaism, 45

17. Dubois, J .A. (1936) Hindu Manners, Customs and Ceremonies. Edition 3rd UK: oxford Clarendon press.

18. Swami Chidananda, (1993) Twenty Important Spiritual publication, A Divine Life Society publications, 35 Worship in the World Religion, 216-217

19. James. Hastings S. (1958) Encyclopedia of Religion and Ethics. New York: Boston Public Library. 10/469

20. Vivekananda. Swami, (1964) Complete Works, (Vol. III, p: 288) India: Advaita Ashram.

21. The Sufi courtyard, "Dargahs of Delhi", 21

22. Takahashi, Y. 2007. A Study on Max Weber's "Ancient Judaism": Theoretical Framework and Methodology. Max Weber Studies, 7(2), 213-229. Retrieved from http://www.jstor.org/stable/2457 9884: 47

23. M. Sinclair Stevenson, 1915, Heart of Jainism, (London: Oxford University Press.

24. Sadia Dehlvi. 2012, The Sufi Courtyard, Darghas of Delhi New Delhi: Harper Collins publisher.

25. Jayaram V, 'Suddhi, Purity and Cleanliness in Hinduism', retrieved from http://www.hinduwebsite. com/hinduism/h_purification.asp

26. Benjamin Walker, 1968, Hindu World, 'An Encyclopedia Survey of Hinduism' Vol: 1 London: George Allen \& Un win Ltd, 359, 126. 